\title{
Contribution of Sulfur Dioxide Concentration from Vehicle Emissions at Integrated Campus of Islamic University of Indonesia
}

\author{
Supriyanto ${ }^{1}$, Andi Wim Ansharullah ${ }^{2}$
}

\begin{abstract}
Sulfur dioxide $\left(\mathrm{SO}_{2}\right)$ is one of air pollutant from vehicle emissions. This study measures $\mathrm{SO}_{2}$ concentration based on experiment and modeling in Integrated Campus of Islamic University of Indonesia between May 4, 2015 to May 8, 2015 . It is useful for master plan development for future. The experiment used pararosanilin method (SNI 19-7119.7-2005) with one-hour sampling and the model applied Gauss Dispersion Model of Line Source Type. The highest concentration with pararosanilin method is $51.909 \mu \mathrm{g} / \mathrm{m}^{3}$ on May $7^{\text {th }}$ at noon in first point sampling (main entrance). Whereas the highest concentration with Gauss Dispersion Model of Line Source Type is $0.0354 \mu \mathrm{g} / \mathrm{m}^{3}$ on May $6^{\text {th }}$ at noon in second point sampling (roundabout). Model explained that the motorcycles emission lead $\mathrm{SO}_{2}$ concentration than other vehicles. Meanwhile compared the model the experiment shows that there is possibility $\mathrm{SO}_{2}$ from other sources. It meets with the $\mathrm{SO}_{2}$ contribution which is below $1 \%$ from vehicles emissions.
\end{abstract}

Keywords - $\mathrm{SO}_{2}$ emissions, Pararosaniline, Gauss Line Source Type, Contribution.

\section{INTRODUCTION}

T SLAMIC University of Indonesia (UII) is one of the biggest university in Yogyakarta. The university annually receives about 6000 students and it will receive more. UII has several campuses in Yogyakarta. Integrated Campus of UII is administration center located at Jalan Kaliurang KM 14,5 Sleman Yogyakarta.

In addition, the growth of student of UII will be proportional to the growth of vehicles. The mobile growth will increase air pollution consisting carbon monoxide (CO), particulate, nitrogen oxide $\left(\mathrm{NO}_{\mathrm{x}}\right)$ and sulfuric oxide $\left(\mathrm{SO}_{\mathrm{x}}\right)$. Meanwhile the air quality standard of Yogyakarta local government (PP 41/1999) for air pollution control is $900 \mathrm{ug}$ $\mathrm{SO}_{2} / \mathrm{Nm}^{3}$ with one hour sampling [1]. The research objective to monitor $\mathrm{SO}_{2}$ concentration from vehicle emission to have recommendation for development of university master plan

\section{METHOD}

This research needs several data from analysis measurement and modeling calculation.

\section{A. Air Sampling}

Sampling point has two locations in the figure 1. The first sampling point is at the main gate near Kahar Muzakir

Supriyanto $^{1}$ is Lecturer at Department of Environmental Engineering, Islamic University of Indonesia

Andi Wim Ansharullah ${ }^{2}$, was researcher at Department of Environmental Engineering, Islamic University of Indonesia
Auditorium (7 $\left.41^{\circ} 14.83^{\prime \prime S}, 110^{\circ} 24^{\prime} 43.60^{\prime \prime} T\right)$ and the Second sampling point is at the roundabout of Integrated campus (7 $\left.41^{\circ} 15.19^{\prime} \mathrm{S}, 110^{\circ} 24^{\prime} 57.87^{\prime} \mathrm{T}\right)$ near with Muhammad Natsir Building. Moreover, one hour sampling times use peak time in the morning (at 08.00-09.00), in the noon (12.00$13.00)$ and in the afternoon (15:30-16:30)

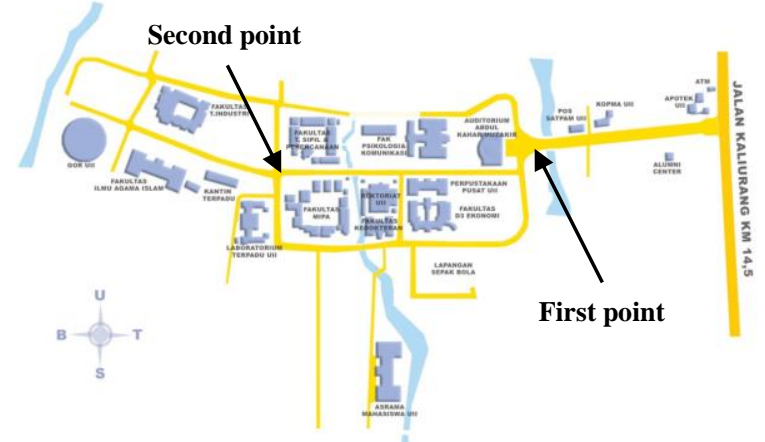

Fig 1. Sampling Point at Integrated Campus of Islamic University of Indonesia

\section{B. Experiment}

Analysis method use pararosanilen method with spectrophotometer (Indonesia National Standard, SNI 197119.7-2005). The figure 2 shows a series of experimental tool for $\mathrm{SO}_{2}$ analysis. The figure description is $\mathrm{A}$, absorbent bottle with $30 \mathrm{~mL}$ volume; $\mathrm{B}$, steam trap; C, glass wool; D, flow meter for measuring air flow $0.2 \mathrm{~L} / \mathrm{min}$; E, control valve; and $\mathrm{F}$, pump. In the other hand, analysis also use Anemometer, 4 in 1 meter tipe LM-8000A; Barometer, PCE-THB 40; Midget Impinger; Spectrofometer Genesys 20 Merk Thermo Spectronic; $0.6 \%$ sulfamate acid; $0.2 \%$ fermaldelhide solution; pararosanilin solution as $\mathrm{SO}_{2}$ absorbent; aquades. After one hour sampling, the $\mathrm{SO}_{2}$ absorbent solution is analyzed by spectrophotometer to get absorbance values.

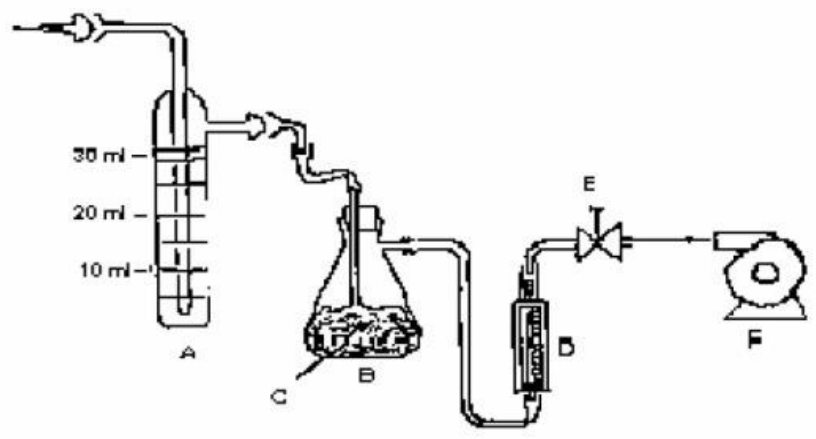

Fig 2. A series of experimental tool for $\mathrm{SO}_{2}$ analysis 
The calculation for the standard volume $(\mathrm{V})(\mathrm{L} / \mathrm{min})$ is function of initial flow rate (F1), final flow rate (F2) (L/min), Sampling pressure $(\mathrm{mmHg})$, sampling temperature $(\mathrm{T})$, standardl temperature $(298 \mathrm{~K})$ and standard pressure (760 $\mathrm{mmHg}$ ).It shows in equation 1

$$
V=\frac{F 1+F 2}{2} \times T \times \frac{P a}{T a} \times \frac{298 \mathrm{~K}}{760 \mathrm{mmHg}}
$$

$\mathrm{SO}_{2}$ concentration in the air sampling is calculated by equation 2. The equation is function of the amount of $\mathrm{SO}_{2}$ for calibration curve $(\mu \mathrm{g})$ divided by standard volume $(\mathrm{V})$

$$
C=\frac{\mathrm{a}}{V} \times \frac{1000 L}{1 m^{3}}
$$

\section{C.Modelling}

Model of Gauss Line Source Type has been done in this research. The model assumes that the air pollutant source of vehicles emissions shapes line [3]. The equation 3 calculates the model. It uses emission rate of vehicles $(\mathrm{g} / \mathrm{s} . \mathrm{m}) ; \pi(3.14)$; $\sigma z$, dispersion coefficient based on vertical z-axis; u, wind speed $(\mathrm{m} / \mathrm{s}) ; \mathrm{h}$ the height of source(exhaust tube) from ground

$$
C_{(x, y)}=\left[\frac{Q}{\sqrt{2 \pi \times \sigma z \times u}}\right] \times e^{\left[-\frac{1}{2} \frac{\mathrm{h}^{2}}{\sigma z^{2}}\right]}
$$

Dispersion coefficient is function of atmosphere stability and distance of source-receptor. It is described by equation 4[4]. Where a,c,d,f is constant depend on the atmosphere stability and $\mathrm{x}$ is distance

$$
\sigma z=c x^{d}+f
$$

The correction of wind speed above 10 meter is explained by equation 5 [5]. With $\mathrm{u}=$ wind speed at monitoring point, $\mathrm{u}_{0}$ = wind speed at known height, $\mathrm{z}=$ height of monitoring point, $\mathrm{z}_{0}=$ known height, $\mathrm{p}=$ dimensionless parameter related atmosphere stability

$$
u=u_{0}\left(\frac{z}{z_{0}}\right)^{p}
$$

TABLE 1

STABILITY ClASS OF PASQUIL-TURNER

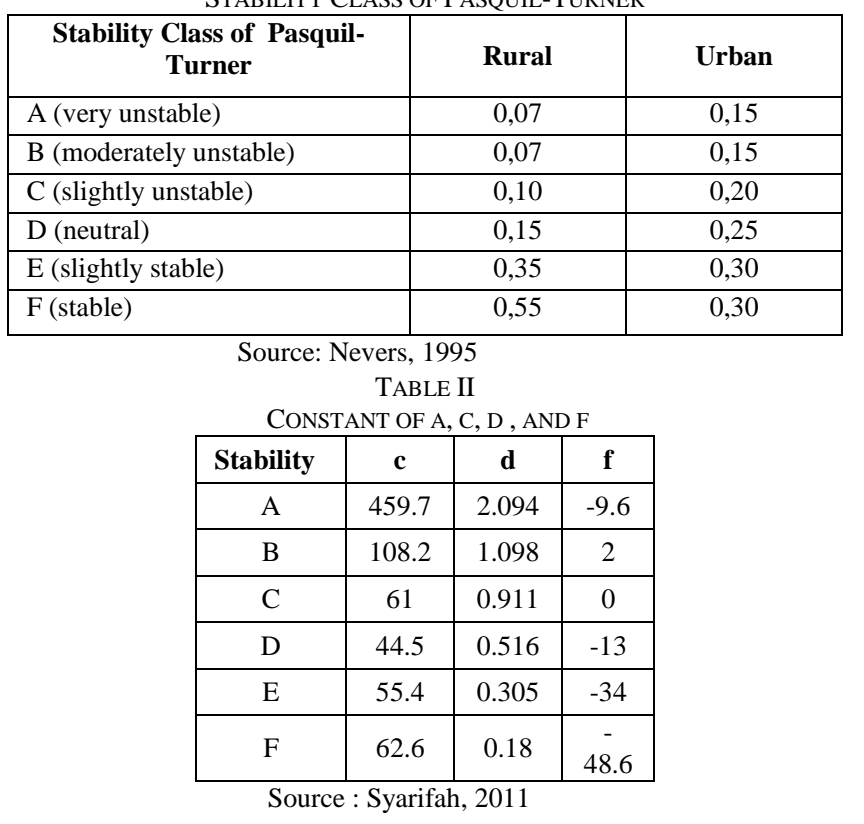

Furthermore, emission factor explain pollutant mass per distance and it is based on the vehicles type [6]. Table 4 sows the emission factor

TABLE IV

EMISSION FACTOR OF VEHICLE

\begin{tabular}{|l|c|}
\hline \multicolumn{1}{|c|}{ Vehicle Type } & $\mathbf{S O}_{\mathbf{2}}(\mathbf{g} / \mathbf{k m})$ \\
\hline Motorcycle & 0.008 \\
\hline Pasenger Car (gasoline fuel) & 0.026 \\
\hline Pasenger Car (diesel fuel) & 0.44 \\
\hline Car & 0.93 \\
\hline Truck & 0.82 \\
\hline \multicolumn{2}{|c|}{ Source Ministry of Environment, 2013}
\end{tabular}

\section{D.SO $\mathrm{S}_{2}$ Contribution}

Contribution of $\mathrm{SO}_{2}$ is calculated by equation [7]. Where $\%$ Contribution, Contribution Percentage; a, experiment data; $\mathrm{b}$, model data.

$\%$ Contribution $=100 \%-\left\{\left[\frac{a-b}{a}\right] \times 100 \%\right\}$

\section{RESUlt AND DISCUSSION}

\section{A. Model and Vehicle Numbers}

Figure 3 and 4 shows that motorcycles dominate vehicles number in integrated campus, so the emission of motorcycle will be higher than other vehicle emission. The motorcycle numbers at second point has about 300 numbers compared at first point. Second point has three entrance consisted main gate, behind gate of UII Laboratory), and beside gate of Faculty of Civil Engineering and Planning)

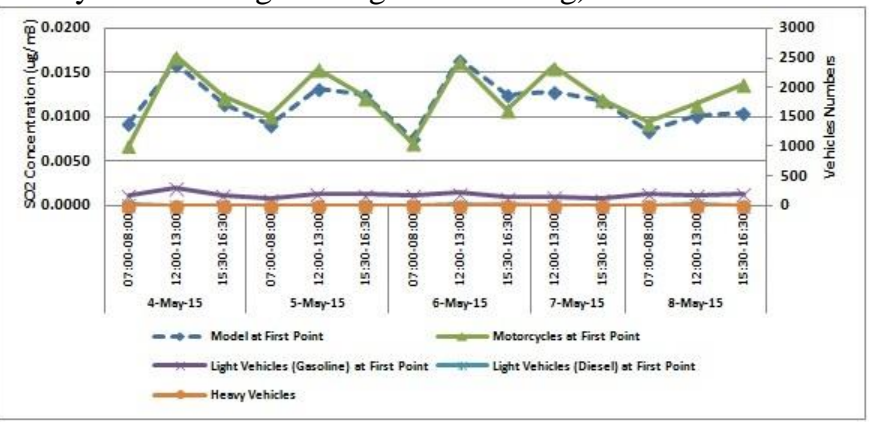

Fig. 3. Vehicle Number at First Point

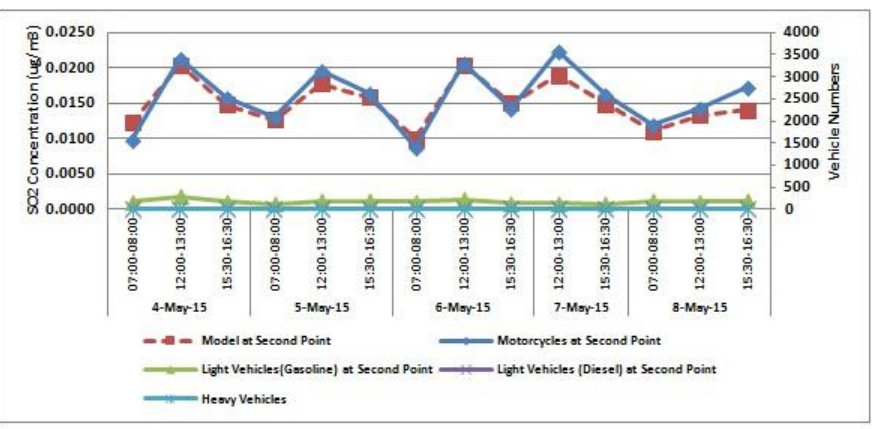

Fig 4. Vehicle Numbers at Second Point 


\section{B. Experiment and Model}

Figure 5 shows the model dan sampling at two sampling point. For experiment, The highest $\mathrm{SO}_{2}$ concentration happen on May 7, 20015 at noon. it is $50 \mu \mathrm{g} / \mathrm{m}^{3}$ at first sampling point and below $50 \mu \mathrm{g} / \mathrm{m}^{3}$ at second sampling point. This result confirm with the 3578 motorcycles in that day. Whereas the lowest $\mathrm{SO}_{2}$ concentration at two sampling point is about 20 $\mu \mathrm{g} / \mathrm{m}^{3}$ on may 4, 2015 with 2515 motorcycles. Meanwhile model calculate $\mathrm{SO}_{2}$ which is below $0.0250 \mu \mathrm{g} / \mathrm{m}^{3}$ at figure 5 . From comparing experiment model and experiment, there are likelihood $\mathrm{SO}_{2}$ from other sources, such as traffic emission of the road way (Kaliurang Street) and fossil fuel combustion for cooking in the several near canteens and housing [8].

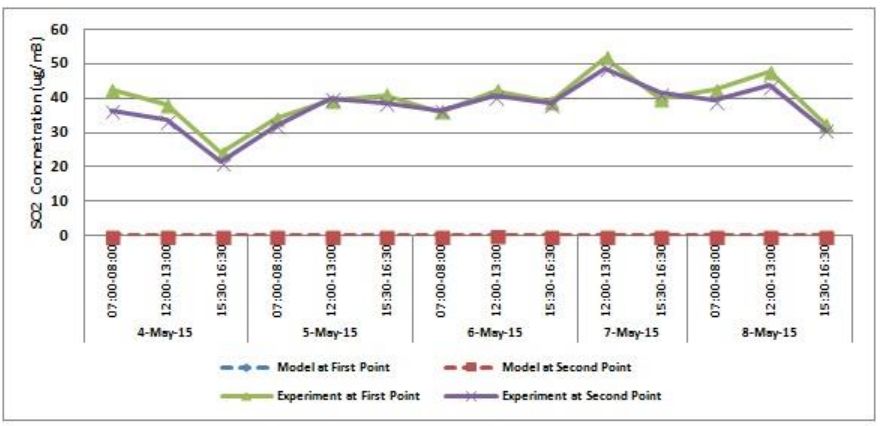

Fig 5. Experiment and Model

\section{C. $\mathrm{SO}_{2}$ Contribution}

Figure 6 shows $\mathrm{SO}_{2}$ contribution from the model compared with the experiment. The highest contributions occur on May 4, 2015 at noon. They are $0.7 \%$ and $0.5 \%$ at first sampling point and second sampling point, respectively. Meanwhile the lowest contribution is $0.3 \%$ at fist sampling point on 6 May, 20115 in the morning. Whereas at second sampling point the lowest contribution also happened on 6 may, 2015 in the morning with $0.2 \%$.

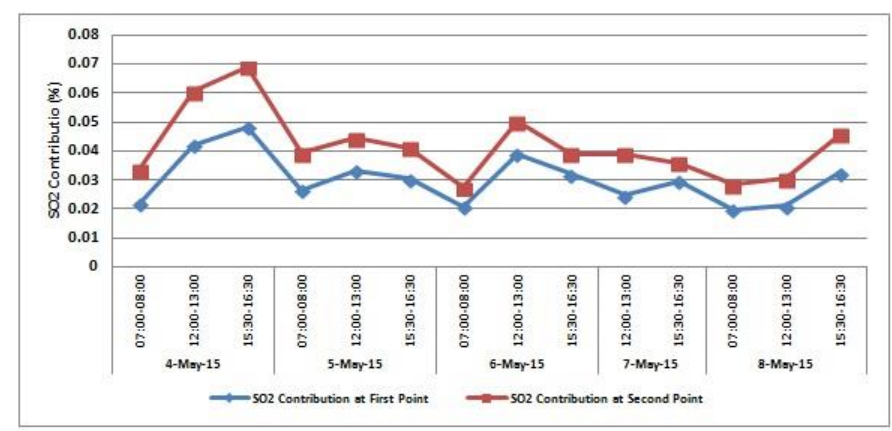

Fig. 6. $\mathrm{SO}_{2}$ Contribution from Vehicle Emission

\section{CONCLUSION}

In this study Pararosanilin Method and Gauss dispersion model line source type has been developed for measuring sulfur dioxide at integrated campus of Islamic University of Indonesia. The model and experiment take two sampling point. From comparing experiment model and experiment, there are possibility $\mathrm{SO}_{2}$ from other sources, such as traffic emission of the road way (Kaliurang Street) and fossil fuel combustion for cooking in the several canteens. The contribution of $\mathrm{SO}_{2}$ emission from vehicles is below $1 \%$.

\section{ACKNOWLEDGMENT}

Authors have thanks to Study Program of Environmental Engineering for financial Support.

\section{REFERENCE}

[1] Governor of Yogyakarta. 2002. "Keputusan Gubernur Propinsi Daerah Istimewa Yogyakarta Nomor 153 Tahun 2002 tentang Baku Mutu Udara Ambien Daerah di Propinsi Daerah Istimewa Yogyakarta. 2002. Yogyakarta.

[2] National Standardization Bodies. 2005. "SNI 19-7119.7-2005 Tentang cara uji kadara sulfur dioksida $\left(\mathrm{SO}_{2}\right)$ dengan metode pararosanilin menggunakan spektrofotometer". Jakarta: Badan Standarisasi Nasional.

[3] Basuki, widodo dan Endrayana, putut, 2011. "Simulasi model disperse polutan karbon monoksida di pintu masuk tol (Studi Kasus Line Source Di Ruas Tol Dupak, Surabaya )". Prosiding Seminar Nasional Penelitian, Pendidikan dan Penerapan MIPA, Fakultas MIPA, Universitas Negeri Yogyakarta, 14 Mei 2011.

[4] Nevers, Noel de.1995, "Handbook of Air Pollution Control Engineering". McGraw-Hill, Inc, Publication, University of Utah.Singapura.

[5] Syarifah, N., Assomadi, A.F. 2012. "Pemodelan disperse sulfur dioksida $\left(\mathrm{SO}_{2}\right)$ dari sumber titik majemuk dengan modifikasi model gauss di jalan pagesangan raya Surabaya selatan". Scientific conference of environmental technology IX-2012 Advances in Agricultural and Municipal Waste Technology to Anticipate Food and Energy Crisis Surabaya, 10 July 2012.

[6] Mininstry of Environment, 2013. "Tentang pedoman penyusunan inventarisasi emisi pencemaran udara di perkotaan". Jakarta: Kementrian Lingkungan Hidup.

[7] Wisnu Wisi Nugroho, Abdu Fadli Assomadi, 2012. "Pemodelan disperse sulfur dioksida $\left(\mathrm{SO}_{2}\right)$ dari sumber garis majemuk dengan modifikasi model gauss di jalan pagesangan raya surabaya selata". Scientific conference of environmental technology IX-2012 Advances in Agricultural and Municipal Waste Technology to Anticipate Food and Energy Crisis Surabaya, 10 July 2012.

[8] Fardiaz, Srikandi, 1992, "Polusi Air danUdara", Kanisius (Anggota IKAPI), Yogyakarta. 